\title{
Performance, intestinal microflora, and blood constituents in finishing turkeys fed diets supplemented with dietary mannan oligosaccharide and live yeast
}

\author{
Y. Konca ${ }^{1}$, F. Kirkpinar' ${ }^{2}$, S. Mert ${ }^{2}$ and B. Kayhan ${ }^{3}$ \\ Ege University, \\ ${ }^{1}$ Odemis Vocational Training School, \\ ${ }^{2}$ Agricultural Faculty, Department of Animal Science \\ 35040 Izmir, Turkey \\ ${ }^{3}$ Odemis Governmental Hospital \\ 35750 Izmir, Turkey
}

(Received 7 August 2008; revised version 31 March 2009; accepted 24 June 2009)

\begin{abstract}
This study was designed to evaluate the effects of dietary mannan oligosaccharide (MOS) and Saccharomyces cerevisiae (SC) in finishing turkeys' diets on performance, intestinal microflora, duodenal viscosity and $\mathrm{pH}$, and blood constituents. A total of seventy-two, Big6, 10-week-old, male poults were divided into three dietary treatments and eight replicate pens per treatment. Treatments including the following: 1. basal diet (control - C, no additive), 2. addition of MOS $1 \mathrm{~g}$ per $\mathrm{kg}$ basal diet, and 3. SC $1 \mathrm{~g}$ per $\mathrm{kg}$ (strain SC47, $300 \times 10^{10} \mathrm{CFU} / \mathrm{kg}$ ) basal diet. The treatments did not affect body weight, duodenal viscosity, and $\mathrm{pH}$. The daily feed intake $(\mathrm{P}<0.01)$ and feed conversion ratio $(\mathrm{P}<0.05)$ in the MOS group were higher than those of the control and $\mathrm{SC}$ groups. The ileum total bacteria, gram negative bacteria and $E$. coli counts in the SC group were lower than those of the control and MOS groups $(\mathrm{P}<0.05)$. The serum triacylglycerols, cholesterol, HDL, LDL, glucose, total protein, albumin, globulin, and creatine concentration of turkey toms were not influenced by the dietary MOS and SC supplementation $(\mathrm{P}>0.05)$.
\end{abstract}

KEY WORDS: turkey, mannan oligosaccharide, live yeast, performance, microflora, blood traits

\footnotetext{
${ }^{1}$ Corresponding author: e-mail: yusufkonca@yahoo.com
} 


\section{INTRODUCTION}

The use of antibiotics for growth promotion in poultry has been banned in many countries. For this reason, the addition of prebiotics and probiotics to a diet for poultry (considered as factors potentially beneficial to the health status and performance resulting from their consumption) has been growing in recent years (Juśkiewicz et al., 2006). The ban of antibiotic usage as feed additives in poultry diets has led to an increase in research carried out on alternative feed additives including prebiotics, for example, mannan oligosaccharide (MOS) and probiotics like Saccharomyces cerevisiae (SC).

As a feed supplement source, $\mathrm{SC}$ is living yeast and MOS derived from the cell wall of the SC yeast. Prebiotics and probiotics are two of the different approaches that have the potential to reduce enteric disease in poultry and subsequent contamination of poultry products. They can alter the intestinal microbiota and immune system to reduce colonization by pathogens in certain conditions (Patterson and Burkholder, 2003). Enteric conditioners, such as MOS and antibiotic growth promoters, ultimately enhance the efficiency of nutrient utilization by reducing the competition between the host and its intestinal microbial inhabitants. Without the microbial competition for energy and other nutrients, the host retains a greater amount of nutrients available for absorption and metabolism. Therefore, probiotics (Patterson and Burkholder, 2003) and MOS have the potential to enhance growth rate, feed efficiency, and livability in poultry species (Shane, 1999; Patterson and Burkholder, 2003). On the other hand, some of the reports failed to observe a positive effect of feeding with yeast on growth performance in turkeys (Bradley and Savage, 1995) and broilers (Batista et al., 2007).

Some up-to-date experiments have been conducted with MOS and live yeast; they revealed some contradictory performance results in poultry. The aim of the current study was to determine the effects of MOS and SC on the performance, intestinal microflora, and blood parameters in finishing turkey toms.

\section{MATERIAL AND METHODS}

\section{Animals and diets}

A total of seventy-two, Big6, male turkeys were obtained from a local commercial hatchery, and they were grown until 10 weeks of age without any treatment. The turkeys were fed diets with a nutrient composition according to NRC (1994) recommendations, relevant to poultry aged 0 to 10 weeks. The turkey toms were individually weighed, then ranked for minimal differences, and selected according to their weights at 10 weeks old. There were three treatment groups, 
including 8 replicates per treatment with 3 birds in each replicate. The treatments included the following: 1 . basal diet (control - $\mathrm{C}$, no additive), 2. basal diet + prebiotic $1 \mathrm{~g}$ per kg feed (mannan oligosaccharide - MOS, Bio-Mos ${ }^{\circledR}$; Alltech Inc., Finland), and 3. basal diet + live yeast $1 \mathrm{~g}$ per $\mathrm{kg}$ feed (Saccharomyces cerevisiae 47 - SC, Kavimix Biosaf ${ }^{\circledR}, 300 \times 1010$ CFU per kg, Kartal Kimya San. Tic. A.Ş., Istanbul). The basal diet was formulated to meet nutrient requirements (NRC, 1994) for 10 to 12,12 to 16 , and 16 to 18 week periods. The MOS and SC were homogeneously mixed with the basal diet. The experimental diets used in this study are given in Table 1.

The experiment lasted from 10 to 20 weeks of age. The turkeys were housed in wire-separated pens ( 2 birds $/ \mathrm{m}^{2}$ ) with floors covered with dry wood shavings. The

Table 1. Composition of experimental diets ${ }^{1}$

\begin{tabular}{|c|c|c|c|}
\hline \multirow{2}{*}{ Item } & \multicolumn{3}{|c|}{ Age, week } \\
\hline & 10 to 12 & 12 to 16 & 16 to 20 \\
\hline \multicolumn{4}{|l|}{ Ingredients, $g$} \\
\hline yellow maize & 460.00 & 500.00 & 550.00 \\
\hline wheat & 148.30 & 186.37 & 199.54 \\
\hline soyabean meal & 345.07 & 264.12 & 198.31 \\
\hline vegetable oil & 12.39 & 18.55 & 25.35 \\
\hline limestone & 11.56 & 13.05 & 11.66 \\
\hline monocalcium phosphate & 14.63 & 10.82 & 8.76 \\
\hline anticoccidial (cocistac) & 1.00 & 1.00 & 1.00 \\
\hline methionine & 0.62 & 0.50 & 0.00 \\
\hline lysine & 1.43 & 0.59 & 0.38 \\
\hline sodium chloride & 2.50 & 2.50 & 2.50 \\
\hline vit.-min. Premix ${ }^{2}$ & 2.50 & 2.50 & 2.50 \\
\hline \multicolumn{4}{|l|}{ Analysed composition, $\%$} \\
\hline dry matter & 89.23 & 89.48 & 90.54 \\
\hline crude protein & 21.32 & 18.33 & 15.91 \\
\hline crude fibre & 3.39 & 3.08 & 2.78 \\
\hline crude ash & 5.50 & 4.92 & 4.27 \\
\hline \multicolumn{4}{|l|}{ Calculated composition ${ }^{3, \%}$} \\
\hline $\mathrm{ME}, \mathrm{MJ} / \mathrm{kg}$ & 12.20 & 12.69 & 13.17 \\
\hline lysine & 1.12 & 0.92 & 0.76 \\
\hline methionine & 0.38 & 0.33 & 0.26 \\
\hline $\mathrm{Ca}$ & 0.89 & 0.81 & 0.72 \\
\hline available $\mathrm{P}$ & 0.40 & 0.34 & 0.29 \\
\hline
\end{tabular}

${ }^{1}$ diets of the experiment was consisted of periodical contained without and with $1 \mathrm{~g} / \mathrm{kg}$ mannan oligosaccharide (Bio-MOS ${ }^{\circledR}$ ) and live yeast (Biosaf ${ }^{\circledR}$, Saccharomyces cerevisiae);

${ }^{2}$ supplied per $\mathrm{kg}$ of the feed, IU: vit. A 15000 , vit. $\mathrm{D}_{3}$ 2000, mg: vit. E 40.0, vit. K 5.0, vit. $\mathrm{B}_{1}$ (thiamin) 3.0, vit. $\mathrm{B}_{2}$ (riboflavin) 6.0 , vit. $\mathrm{B}_{6} 5.0$, vit. $\mathrm{B}_{12} 0.03$, niacin 30.0 , biotin 0.1 , calcium D-pantothenate 12, folic acid 1.0, choline chloride 400, Mn 80.0, Fe 35.0, Zn 50.0, Cu 5.0, I $2.0, \mathrm{Co} 0.4, \mathrm{Se} 0.15 ;{ }^{3}$ the $\mathrm{ME}$, lysine, methionine, $\mathrm{Ca}$ and available $\mathrm{P}$ contents of feeds were calculated according to NRC (1994) 
lighting schedule was $16 \mathrm{~L}: 8 \mathrm{D}$ (darkness from 10.30 p.m. to 6.30 a.m.). Feed and water were provided ad libitum. The individual body weight and feed intake (FI) by pen bases were obtained at 10,12,14,16, 18 and 20 weeks. Feed conversion ratio and body weight gain at each stage were calculated. Mortality did not occur.

Dry matter, crude protein and ether extract of feeds were determined according to AOAC (1980), and crude fibre content was determined according to Nauman and Bassler (1993).

\section{Determination of microbial counts}

Two toms per pen (16 each, total of 48) were randomly chosen and killed by cervical dislocation at 20 weeks of age, and the gastrointestinal tract was excised. From jejunum and ileum, $1 \mathrm{~g}$ of the digesta samples were collected, diluted with $1 \mathrm{ml}$ serum physiologic $(0.85 \% \mathrm{NaCl})$, and homogenized for $3 \mathrm{~min}$. Tenfold dilutions with the sterile solution of physiological salt were prepared from the initial water samples. Then, $5 \mu 1$ of the examined liquid was taken from each dilution, evenly spread on the surface of the agar media in 2 parallel repetitions, and incubated at $37^{\circ} \mathrm{C}$ for $24 \mathrm{~h}$. After the incubation colonies were counted, the concentration of the bacterial microflora in the samples were determined with appropriate agar media; $5 \%$ sheep blood agar (bioMérieux, France) was used to determine the total number of bacteria (TB), and eosine methylene blue agar (EMB, bioMérieux, France) was used to identify E. coli (EC) and gram negative bacteria (GNB) counts. The microbial counts were determined as colony-forming units ( $\mathrm{CFU}$ ) per gram of samples (Gunal et al., 2006).

\section{Determination of duodenal $\mathrm{pH}$ and viscosity}

The $\mathrm{pH}$ value of the duodenal digesta was determined with a $\mathrm{pH}$ meter (Hanna Instruments-8413). The duodenum (pancreatic loop) was carefully excised. Several eppendorf tubes were filled from each sample, labeled, and centrifuged (4000 $\mathrm{g}$ for $10 \mathrm{~min}$ ). The supernatant was withdrawn, and the viscosity of a $0.5 \mathrm{ml}$ aliquot was measured using a Brookfield Digital Viscometer (Model DV-II+PRO, Brookfield Engineering Laboratories, Stoughton, MA, USA) maintained at $40^{\circ} \mathrm{C}$ and expressed in $\mathrm{cP}$.

\section{Blood biochemical analysis}

Blood samples were obtained by vena puncture of the left wing vein from two toms in each pen (total 48 toms) at 20 weeks of age for blood chemical analysis. Then, blood samples were kept on ice, transferred to the laboratory, and centrifuged at $1500 \mathrm{~g}$ for $10 \mathrm{~min}$; the serums were removed and stored at 
$-20^{\circ} \mathrm{C}$ until analysed. The serum triacylglycerols, cholesterol, HDL, LDL, glucose, total protein, albumin, globulin and creatine concentrations were measured by using the kits from the same manufacturer with an auto-analyzer (BT 3000 plus, Biotechnica, Rome, Italy).

\section{Statistical analysis}

Data were subjected to ANOVA using General Linear Models (SAS, 1996). The model included the type of dietary control MOS and SC present. The differences among means were tested using Duncan's multiple-range tests.

\section{RESULTS}

Performance traits. The body weight (BW), daily feed intake (DFI) and feed conversion ratio (FCR) values of toms were presented in Table 2. The dietary MOS and SC supplementation did not significantly improve the BW of toms.

Table 2. Effect of the dietary treatments on body weight (BW), daily feed intake (DFI) and feed conversion ratio (FCR) in turkey toms

\begin{tabular}{|c|c|c|c|c|c|}
\hline \multirow{2}{*}{ Age, week } & \multicolumn{3}{|c|}{ Dietary treatment } & \multirow{2}{*}{$\mathrm{P}$} & \multirow{2}{*}{ SEM } \\
\hline & control & MOS & S. cerevisiae & & \\
\hline \multicolumn{6}{|c|}{$\overline{\text { Body weight, } \mathrm{kg}}$} \\
\hline 10 & 7.01 & 7.12 & 7.04 & NS & 0.11 \\
\hline 12 & 8.03 & 8.24 & 8.07 & NS & 0.12 \\
\hline 14 & 10.12 & 10.32 & 10.17 & NS & 0.13 \\
\hline 16 & 11.92 & 12.15 & 11.88 & NS & 0.14 \\
\hline 18 & 13.69 & 13.91 & 13.72 & NS & 0.19 \\
\hline 20 & 15.67 & 16.02 & 15.78 & NS & 0.23 \\
\hline \multicolumn{6}{|l|}{$D F I, g / d$} \\
\hline 10 to 12 & $352.4^{\mathrm{b}}$ & $487.5^{\mathrm{a}}$ & $407.7^{\mathrm{ab}}$ & $* *$ & 19.14 \\
\hline 12 to 14 & 401.4 & 414.8 & 400.6 & NS & 9.86 \\
\hline 14 to 16 & 415.4 & 420.7 & 406.2 & NS & 18.46 \\
\hline 16 to 18 & 471.9 & 512.9 & 467.0 & NS & 20.70 \\
\hline 18 to 20 & 508.1 & 494.8 & 495.5 & NS & 14.53 \\
\hline 10 to 20 & $427.2^{\mathrm{b}}$ & $471.8^{\mathrm{a}}$ & $435.4^{\mathrm{b}}$ & $* *$ & 9.20 \\
\hline \multicolumn{6}{|c|}{ FCR, feed/gain } \\
\hline 10 to 12 & 1.54 & 2.02 & 1.75 & NS & 0.09 \\
\hline 12 to 14 & 2.70 & 2.80 & 2.68 & NS & 0.09 \\
\hline 14 to 16 & 3.25 & 3.22 & 3.36 & NS & 0.18 \\
\hline 16 to 18 & 3.73 & 4.43 & 3.54 & NS & 0.28 \\
\hline 18 to 20 & 3.90 & 3.56 & 3.47 & NS & 0.37 \\
\hline 10 to 20 & $3.03^{\mathrm{b}}$ & $3.21^{\mathrm{a}}$ & $2.96^{\mathrm{b}}$ & $*$ & 0.10 \\
\hline
\end{tabular}


The DFI of the toms fed with MOS was higher than those of the control group at 10 to 12 weeks and the control and SC groups at the 10 -to-20-wk period $(\mathrm{P}<0.01)$. Also, the FCR in the MOS group was higher than those of the control and SC groups at the overall period $(\mathrm{P}<0.05)$.

Microbial count and viscosity. The total bacteria (TB), gram negative bacteria (GNB) and E. coli (EC) counts of the ileum and jejunum of the toms were presented in Table 3. The TB count in the SC group was lower than those of the control and MOS groups, while the GNB and EC counts were lower than that of the control group in the ileum $(\mathrm{P}<0.05)$. However, these microorganism counts were not statistically affected in the jejunum $(\mathrm{P}>0.05)$. Also, duodenal viscosity and $\mathrm{pH}$ were not affected by the treatments.

Table 3. Effect of the dietary treatments on gastrointestinal system microflora count $\left(\mathrm{X} 10^{3} \mathrm{CFU} / \mathrm{ml} / \mathrm{g}\right.$ ) and duodenal viscosity and $\mathrm{pH}$ in turkey toms

\begin{tabular}{|c|c|c|c|c|c|}
\hline \multirow{2}{*}{ Item, $\mathrm{X} 10^{3} \mathrm{CFU} / \mathrm{ml} / \mathrm{g}$} & \multicolumn{3}{|c|}{ Dietary treatment } & \multirow{2}{*}{$\mathrm{P}$} & \multirow{2}{*}{ SEM } \\
\hline & control & MOS & S. cerevisiae & & \\
\hline \multicolumn{6}{|l|}{ Ileum } \\
\hline total bacteria & $264.3^{\mathrm{a}}$ & $235.0^{\mathrm{a}}$ & $95.6^{\mathrm{b}}$ & $*$ & 5.2 \\
\hline gram negative bacteria & $196.7^{\mathrm{a}}$ & $155.0^{\mathrm{ab}}$ & $59.4^{\mathrm{b}}$ & $*$ & 36.2 \\
\hline Escherichia coli & $166.7^{\mathrm{a}}$ & $121.7^{\mathrm{ab}}$ & $46.5^{\mathrm{b}}$ & * & 31.7 \\
\hline \multicolumn{6}{|l|}{ Jejunum } \\
\hline total bacteria & 457.1 & 388.6 & 493.7 & NS & 51.7 \\
\hline gram negative bacteria & 357.6 & 342.5 & 362.5 & NS & 65.0 \\
\hline Escherichia coli & 271.4 & 247.5 & 267.5 & NS & 51.3 \\
\hline Duodenal viscosity (cP) & 1.33 & 1.33 & 1.25 & NS & 0.10 \\
\hline Duodenal pH & 6.19 & 6.10 & 6.13 & NS & 0.06 \\
\hline
\end{tabular}

MOS - mannan oligosaccharide; P - probability; SEM - standard error of the means (Pooled); * $-\mathrm{P}<0.05$; ** $-\mathrm{P}<0.01$; NS - non-significant; ${ }^{\mathrm{a}, \mathrm{b}}$ - means within the same row with different superscript are significant

Blood traits. The blood constituent of the toms was presented in Table 4. The dietary MOS and SC supplementation did not affect the serum triacylglycerols, cholesterol; HDL, LDL, glucose, total protein, albumin, globulin and creatine concentration of turkey toms $(\mathrm{P}>0.05)$.

\section{DISCUSSION}

Dietary SC and MOS supplementation did not significantly affect the BW of the turkey toms compared with the control. In agreement with our results, in a comparative study, Cömert (2004) reported that the BW and gain were not affected by the dietary MOS and probiotic addition in bronze turkeys which advanced in 
Table 4. Effect of the dietary treatments on blood constituent in turkey toms, mg/l

\begin{tabular}{|c|c|c|c|c|c|}
\hline \multirow{2}{*}{$\begin{array}{l}\text { Blood } \\
\text { constituents }\end{array}$} & \multicolumn{3}{|c|}{ Dietary treatment } & \multirow{2}{*}{$\mathrm{P}$} & \multirow{2}{*}{ SEM } \\
\hline & control & MOS & S. cerevisiae & & \\
\hline Triacylglycerols & 445.0 & 331.3 & 348.8 & NS & 75.8 \\
\hline Cholesterol & 1242.5 & 1078.7 & 1076.3 & NS & 69.8 \\
\hline HDL & 566.3 & 495 & 501.3 & NS & 34.0 \\
\hline LDL & 587.5 & 521.3 & 516.3 & NS & 83.4 \\
\hline Glucose & 2571.2 & 2642.5 & 2827.5 & NS & 37.0 \\
\hline Total protein & 34.2 & 34.4 & 34.8 & NS & 1.4 \\
\hline Albumin & 15.8 & 15.4 & 15.0 & NS & 0.6 \\
\hline Globulin & 18.4 & 19.0 & 19.8 & NS & 1.0 \\
\hline Creatine & 1.6 & 1.8 & 1.8 & NS & 0.2 \\
\hline
\end{tabular}

MOS - mannan oligosaccharide; P - probability; SEM - standard error of the means (Pooled); NS - non-significant; HDL - high density lipoprotein; LDL - low density lipoprotein

weeks (from 7 to 21 weeks). Similarly, Batista et al. (2007) reported that the BW and gain were not affected by both prebiotic and probiotic supplementation in broilers. In contrast to other investigations with MOS, improvements in the BW or gain have been reported (Stanley et al., 2000; Sims et al., 2004). In the current study, the DFI and FCR of the toms fed with MOS were higher than those of the control and SC groups at the end of the experimental period. The high DFI in the MOS group may be the result of the changing status of the digestive system. There is substantial evidence that dietary MOS modifies the morphology and structure of the intestinal mucosa (Shane, 1999), the digestive enzyme activities, and the amino acid transport in digestive system (Iji et al., 2001). Hence, in the initial period of the experiment (10 to 12 weeks), most likely, the toms may experience an adaptation process. In this period, feed consumption in the MOS and SC groups were higher than that of the control group (about 38 and 15\%, respectively). However, in the subsequent periods, these differences disappeared. Cömert (2004) reported that the DFI and FCR were not affected by the dietary MOS and probiotic addition in bronze turkeys from 7 to 21 weeks. Similarly, Zduńczyk et al. (2004) noted that dietary MOS supplementation had no significant influence on the DFI and FCR of turkeys at 0 to 8 weeks. However, these results contradict the findings of Sims et al. (2004), who reported that dietary MOS supplementation $(0.1 \%$ to 6 week and $0.05 \%$ thereafter) led to an improvement in the body weight gain and feed conversion ratio in male turkeys.

In this experiment, turkeys were fed a diet supplemented with MOS and SC at the level $(1 \mathrm{~g}$ per $\mathrm{kg}$ of diet) recommended by the companies. The recommended level of MOS in the diet for turkeys was estimated at $0.5-1.0 \mathrm{~g} / \mathrm{kg}$ to 6 weeks then $0.5 \mathrm{~g} / \mathrm{kg}$, according to the producer company (Bio-MOS ${ }^{\circledR}$, Alltech Inc., Finland). On the other hand, Juśkiewicz et al. (2006) found that the addition of MOS to a 
diet was most effective when MOS was applied for a long-term feeding period (16 weeks of feeding) and at a higher dose than $0.1 \%$. Therefore, the level of MOS and SC generally recommended by the companies could be too low to be efficient in the finishing turkeys' diets.

In the present study, neither MOS nor SC supplementations affected jejunal microorganism populations. A comparative study by Ceylan et al. (2003), who reported on MOS and probiotics, did not affect the caecal microflora in broilers. Sims et al. (2004) noted that no effect of MOS was determined on coliform bacteria concentrations in turkeys. In contrast to our results, Zduńczyk et al. (2005) and Juśkiewicz et al. (2006) reported that MOS supplementation reduced caecal EC counts in turkeys. However, in the current study, dietary SC supplementation reduced the ileum concentration of TB, GNB and EC populations, but MOS did not affect these microorganism counts. It is reported that GNB strains could be inhibited with mannose (Spring et al., 2000) and probiotics (Gunal et al., 2006). It is generally accepted that the effectiveness of prebiotics and probiotics depends on the presence of undesirable microorganisms in house or animal. Therefore, enhanced growth performance of birds receiving dietary probiotics or prebiotics depends largely on the consequent diminishing of the undesirable microbial concentration of the gastrointestinal tract, which competes with the host for nutrients (Brzóska et al., 1999).

In the current study, the viscosity of duodenum was not significantly affected by the dietary treatments. MOS is derived from the cell walls of certain strains of $\mathrm{SC}$, and therefore, the product contains a high level of $\beta$-glucan. It is known that $\beta$-glucan increases gut viscosity and affects nutrient digestion and absorption in poultry. As seen in our results, McCan et al. (2006) reported that the viscosity values of the MOS group was similar to those of the other diets, and it is probable that the level of $\beta$-glucan present in MOS was not sufficient to affect in vitro viscosity. It can, therefore, be concluded that the $\beta$-glucan present in MOS did not reveal an anti-nutritive effect and viscosity as shown by McCan et al. (2006). Duodenal $\mathrm{pH}$ was not affected by the treatments. Spring et al. (2000) and Zduńczyk et al. (2005) found that the $\mathrm{pH}$ of ileal and caecal contents were unaffected by dietary MOS supplementation.

The serum components of the turkey toms were not influenced by dietary MOS and SC supplementation. Stanley et al. (2000) observed that serum components were not influenced by the dietary oligosaccharide. In contrast to our findings, it is reported that serum total cholesterol and triglyceride concentrations were reduced by dietary MOS (Kannan et al., 2005) and probiotics (Kalavathy et al., 2003). Prebiotic supplementation could have enhanced the Lactobacillus count; therefore, the decrease in cholesterol concentration may be caused by the assimilation made by the probiotics. Probiotics, such as Lactobacillus, have the ability to synthesize 
bile salt hydrolase enzymes, which deconjugates bile salts, and since cholesterol is the precursor of bile salts, more cholesterol is taken out of circulation (Kalavathy et al., 2003).

\section{CONCLUSIONS}

In conclusion, the effectiveness of mannan oligosaccharide and Saccharomyces cerevisiae (SC) on the performance traits of finishing turkeys' diets is questionable as potential growth promoters. However, there is a potential to decrease pathogenic microorganism in the gastrointestinal system by SC supplementation.

\section{REFERENCES}

AOAC, 1980. Association of Official Analytical Chemist, Official Methods of Analysis. $13^{\text {th }}$ Edition. Washington, DC

Batista L.S., Garcia E.A., Faitarone A.B.G., 2007. Flavonoids and mannanoligosaccharides in broiler diets. Braz. J. Poultry Sci. 9, 33-37

Bradley G.L., Savage T.F., 1995. The effect of autoclaving a yeast culture of Saccharomyces cerevisiae on turkey poultry performance and the retention of gross energy, and selected minerals. Anim. Feed Sci. Tech. 55, 1-7

Brzóska F., Grzybowski R., Steck K., Pieszka M., 1999. Nutritive efficiency of selected probiotic microorganisms in chicken broiler. Rocz. Nauk. Zoot. 26, 291-301

Ceylan N., Çiftçi İ., İlhan Z., 2003. The effects of some alternative feed additives for antibiotic growth promoters on the performance and gut microflora of broiler chicks. Turk J. Vet. Anim. Sci. 27, 727-733

Cömert N., 2004. The effects of avilamycin, bio-moss, cylactin and yucca schidigera extract added to the corn-soybean meal based diets on fattening performance, slaughter results and some blood and intestinal parameters of male broiler turkey. PhD. Thesis, Ankara University, Natural and Applied Sciences Department of Animal Science, pp. 57

Gunal M., Yayli G., Kaya O., Karahan N., Sulak O., 2006. The effects of antibiotic growth promoter, probiotic or organic acid supplementation on performance, intestinal microflora and tissue of broilers. Int. J. Poultry Sci. 5, 149-155

Iji P.A., Saki A.A., Tivey D.R., 2001. Intestinal structure and function of broiler chickens on diets supplemented with a mannan oligosaccharide. J. Sci. Food Agr. 81, 1186-1192

Juśkiewicz J., Zduńczyk Z.J., Jankowski J., 2006. Growth performance and metabolic response of the gastrointestinal tract of turkeys to diets with different levels of mannan-oligosaccharide. World Poultry Sci. J. 62, 612-625

Kalavathy R., Abdullah N., Jalaludin S., Ho Y.W., 2003. Effects of Lactobacillus cultures on growth performance, abdominal fat deposition, serum lipids and weight of organs of broiler chickens. Brit. Poultry Sci. 44, 139-144

Kannan M., Karunakaran R., Balakrishnan V., Prabhakar T.G., 2005. Influence of prebiotics supplementation on lipid profile of broilers. Int. J. Poultry Sci. 4, 994-997

McCann M.E.E., Newell E., Preston C., Forbes K., 2006. The use of mannan-oligosaccharides and/ or tannin in broiler diets. Int. J. Poultry Sci. 5, 873-879 
Naumann C., Bassler R., 1993. Methodenbuch, Band III: Die Chemische Untersuchung von Futtermitteln. VDLUFA-Verlag, Darmstadt (Germany)

NRC, 1994. Nutrient Requirements of Poultry. National Research Council. 9 $^{\text {th }}$ revised Edition. National Academy Press. Washington, DC

Patterson J.A., Burkholder K.M., 2003. Application of prebiotics and probiotics in poultry production. Poultry Sci. 82, 627-631

SAS, 1996. SAS User's Guide: Statistics. SAS Institute. Cary, NC

Shane S.M., 1999. Global climatic effects on livestock and human health. In: T.P. Lyons, K.A. Jacques (Editors). Biotechnology in the Feed Industry. Proceedings of Alltech's $15^{\text {th }}$ Annual Symposium. Nottingham University Press, Nottingham (UK), pp. 357-368

Sims M.D., Dawson K.A., Newman K.E., Spring P., Hooge D.M., 2004. Effects of dietary mannan oligosaccharide, bacitracin methylene disalicylate, or both on the live performance and intestinal microbiology of turkeys. Poultry Sci. 83, 1148-1154

Spring P., Wenk C., Dawson K.A., Newman K.E., 2000. The effects of dietary mannanoligosacharides on cecal parameters and the concentrations of enteric bacteria in the ceca of salmonella-challenged broiler chicks. Poultry Sci. 79, 205-211

Stanley V.G., Brown C., Sefton A.E., 2000. Comparative evaluation of a yeast culture, mannan oligosaccharide and an antibiotic on performance of turkeys. Poultry Sci. 79, Supp.1, 117 (Abstr.)

Zduńczyk Z., Juskiewicz J., Jankowski J., Biedrzycka E., Koncicki A., 2005. Metabolic response of the gastrointestinal tract of turkeys to diets with different levels of mannan-oligosaccharide. Poultry Sci. 84, 903-909

Zduńczyk Z., Juśkiewicz J., Jankowski J., Koncicki A., 2004. Performance and caecal adaptation of turkeys to diets without or with antibiotic and with different levels of mannan-oligosaccharide. Arch. Anim. Nutr. 58, 367-378 